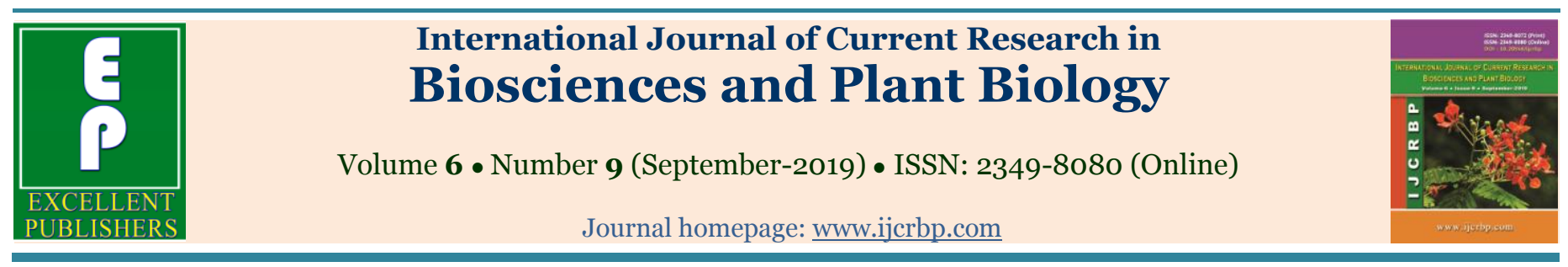

\title{
Inheritance of morphological traits for drought tolerance in rabi sorghum [Sorghum bicolor (L.) Moench]
}

\author{
Snehal A. Tambe1* ${ }^{*}$ D. V. Kusalkar², G. S. Shinde ${ }^{1}$ and M. S. Shinde3 \\ ${ }^{1}$ Department of Botany, Mahatma Phule Krishi Vidyapeeth, Rahuri, Ahmednagar, Maharashtra, India \\ ${ }^{2}$ Associate Director of Research ZARS, Igatpuri, MPKV, Rahuri, Ahmednagar, Maharashtra, India \\ 3All India Coordinated Sorghum Improvement Project, M.P.KV., Rahuri, Ahmednagar, Maharashtra, India \\ *Corresponding author; e-mail: avinashjondhale51@gmail.com
}

\begin{tabular}{|c|c|}
\hline Article Info & ABSTRACT \\
\hline $\begin{array}{l}\text { Date of Acceptance: } \\
16 \text { August } 2019\end{array}$ & \multirow{3}{*}{$\begin{array}{l}\text { The significance of scaling test 'A', 'B', 'C' and ' } \mathrm{D} \text { ' indicated the presence of all } \\
\text { three types of non-allelic gene interaction effects for physiological traits } \\
\text { governed by additive }(d) \text { gene effects along with predominant of dominance } x \\
\text { dominance (l) non-allelic gene interaction effect was important in the } \\
\text { inheritance of traits associated with drought tolerance viz., days to } 50 \text { per cent } \\
\text { flowering, days to physiological maturity, plant height, 10oo grain weight, } \\
\text { harvest index, dry fodder yield per plant and grain yield/plant in which } \\
\text { duplicate epistasis was involved in the expression of all these traits and parent } \\
\text { RSV } 1237 \text { was found superior in contributing all traits viz., days to } 50 \text { per cent } \\
\text { flowering, days to physiological maturity, plant height, } 1000 \text { grain weight, dry } \\
\text { fodder yield per plant and grain yield/plant while parent RSV } 1703 \text { was found } \\
\text { superior in contributing harvest index in cross RSV } 1237 \times \text { RSV } 1703 \text {. An } \\
\text { investigation on generation mean analysis involving six generations }\left(\mathrm{P}_{1}, \mathrm{P}_{2}, \mathrm{~F}_{1} \text {, }\right. \\
\mathrm{F}_{2}, \mathrm{~B}_{1} \text { and } \mathrm{B}_{2} \text { ) of the cross RSV1237 } \mathrm{x} \text { RSV } 1703 \text { in rabi sorghum was carried out } \\
\text { for the traits associated with drought resistance under non stress and moisture } \\
\text { stress condition. }\end{array}$} \\
\hline Keywords & \\
\hline $\begin{array}{l}\text { Drought } \\
\text { Generation mean } \\
\quad \text { analysis } \\
\text { Inheritance traits } \\
\text { Moisture stress } \\
\text { Rabi sorghum }\end{array}$ & \\
\hline
\end{tabular}

\section{Introduction}

Sorghum [Sorghum bicolor (L.) Moench] is an important cereal crop which is grown globally for food and fodder purpose. It is most widely grown in the semi-arid tropics where water availability is limited and frequently subjected to drought. India ranks first in terms of area under sorghum (5.82 M ha), while it ranks second in production i.e 4.5 MT (USDA 2017). The productivity of sorghum in India (854 kg ha-1) is much less than the world average of $1457 \mathrm{~kg}$ ha-1 (FAO 2016). It is most widely grown in the semi-arid tropics where water availability is limited and frequently subjected to drought. Drought limits the agricultural production by preventing the crop plants from expressing their full genetic potential. Production of sorghum in semi-arid regions of the world is limited by drought. Developing plant type has an advantage under water limited condition and is the major challenge for sorghum improvement programme. The low yield of rabi sorghum in 
Maharashtra as compared to national and world average is mainly because of its cultivation under stored residual soil moisture conditions in marginal soils. The rabi sorghum is normally grown under stored and receding soil moisture conditions with increasing temperature after flowering. The limited availability of water causes moisture stress, which affects various metabolic processes of the plant. Drought tolerance in rabi sorghum, is considered to be the product expression of many morphological, physiological and biochemical traits, therefore it is necessary to know the genetics of traits related with drought tolerance. The knowledge of gene actions helps in the selection of parents for hybridization programme and to apply appropriate breeding procedure (Anderson and Kempthrone (1954), Gamble (1962). is necessity of the plant breeder, to know the genetics of drought tolerance in sorghum toevolve promising genotype either through conventional breeding or biotechnological approach. Hence, to initiate a judicious breeding programme, plant breeder must know the nature of gene action involved in the expression of various quantitative characters.

\section{Materials and methods}

The experimental material for generations mean study was comprised of $\mathrm{P}_{1}, \mathrm{P}_{2}, \mathrm{~F}_{1}, \mathrm{~F}_{2}, \mathrm{~B}_{1}$ and $\mathrm{B}_{2}$ generations of cross RSV $1237 \times$ RSV 1703. The parents involved in this cross have considerable variation for quantitative characters, physiological characters and drought tolerance with good grain quality. Two field trials comprising of six different generations of cross, replicated thrice were conducted under non stress (Normal) and moisture stress (Rainout Shelter) conditions during rabi 2015-16 at Sorghum Improvement Project, M.P.K.V., Rahuri. The generations viz., $\mathrm{P}_{1}$, $\mathrm{P}_{2}, \mathrm{~F}_{1}, \mathrm{~B}_{1}$ and $\mathrm{B}_{2}$ were represented by two rows and $\mathrm{F}_{2}$ 's by six rows each having 3.0 meter length in each replication. Seeds were dibbled at $15 \mathrm{~cm}$ distance in rows spaced $45 \mathrm{~cm}$ apart. The recommended fertilizer dose and plant protection measures were followed. Randomly selected competent five plants in $\mathrm{P}_{1}, \mathrm{P}_{2}$ and $\mathrm{F}_{1}$ generations, 10 plants in $B_{1}$ and $B_{2}$ generations and 20 plants in $\mathrm{F}_{2}$ generation in each treatment were selected for recording observations in each replication. The mean values recorded for various characters from observational plants, were used for statistical analysis and computed for the characters viz., days to 50 per cent flowering, days to physiological maturity, plant height, 1000 grain weight, harvest index, dry fodder yield per plant and grain yield/plant associated with cross RSV $1237 \mathrm{x}$ RSV 1703. To provide information on the nature of gene action governing the traits under study, all the six parameters of generation means were calculated following the method outlined by Hayman (1958). To test the adequacy of additive dominance model A, B, C, and D scaling test were applied. The individual scaling test indicated that all or either A. B, C, and D significantly deviated from zero for all the characters, which indicated the presence of non-allelic interaction. Three tests of scale were carried out to detect presence or absence of gene interaction by Mather (1949).

\section{Results and discussion}

Drought tolerant is a complex trait, expression of which depends on action and interaction of different morphological, physiological and biochemical characters. The management practices and breeding efforts is important aspect for better understanding of effects of drought on sorghum crop. Drought tolerance mechanism can be studied based on the interpretation of relationship between leaf structure function and stress tolerance. Despite the progress in sorghum breeding, lack of knowledge about genetic basis of drought tolerant, unavailability of appropriate gene to develop transgenic plant, limited information on inheritance and behavior of major characters, lack of precise screening techniques are the main constraints for genetic improvement of drought tolerant.

From the estimates of mean performance, it was observed that parent RSV 1237 and RSV 1703 exhibited better average performance, either individually or in combinations for all the characters associated with drought tolerance under non stress and moisture stress condition viz., days to 50 per cent flowering, days to physiological maturity, plant height, 1000 grain weight, harvest index, dry fodder yield per plant and grain yield/plant (Table 1). On the basis of results obtained from the present investigations the parent RSV 1237 and RSV 1703are found to be most promising and may be considered in developing drought tolerant genotype in breeding 
program. The scaling test all or either 'A', 'B', ' $\mathrm{C}$ ' and ' $D$ ' were highly significant, indicated the presence of all three types of non-allelic gene interaction effects viz., additive $\mathrm{x}$ additive (i), additive $x$ dominance (j) and dominance $x$ dominance (l) and provided information about all six genetic parameters viz., $\mathrm{m}, \mathrm{d}, \mathrm{h}, \mathrm{i}, \mathrm{j}$ and $\mathrm{l}$. Looking to the opposite sign of dominance (h) and dominance $\mathrm{x}$ dominance (l) reported the duplicate type of the epistasis played an important role in the expression of all the studied traits. The similar findings for non stress condition were reported earlier by Baskheti and Bhatt (2005) and Karande (2015). While the similar findings for moisture stress condition were reported earlier by Narain et al. (2007), Khot (2008) and Lad (2009).

Table 1. Mean performance of different generations for yield and yield contributing characters under non stress and moisture stress condition in rabi sorghum.

\begin{tabular}{|c|c|c|c|c|c|c|c|}
\hline \multirow{2}{*}{$\begin{array}{l}\text { Sr. } \\
\text { No. }\end{array}$} & \multirow{2}{*}{ Generations } & \multicolumn{2}{|c|}{ Days to $50 \%$ flowering } & \multicolumn{2}{|c|}{$\begin{array}{l}\text { Days to physiological } \\
\text { maturity }\end{array}$} & \multicolumn{2}{|c|}{$\begin{array}{l}\text { Plant height } \\
\text { (cm/plant) }\end{array}$} \\
\hline & & $\begin{array}{l}\text { Non } \\
\text { stress }\end{array}$ & $\begin{array}{l}\text { Moisture } \\
\text { stress }\end{array}$ & $\begin{array}{l}\text { Non } \\
\text { stress }\end{array}$ & $\begin{array}{l}\text { Moisture } \\
\text { stress }\end{array}$ & $\begin{array}{l}\text { Non } \\
\text { stress }\end{array}$ & $\begin{array}{l}\text { Moisture } \\
\text { stress }\end{array}$ \\
\hline 1 & $\mathrm{P}_{1}$ & $87.53^{*}$ & $65.40^{*}$ & $128.60^{*}$ & $120.60^{*}$ & $196.73^{*}$ & $177.20^{*}$ \\
\hline 2 & $\mathrm{P}_{2}$ & 95.00 & 71.07 & 136.00 & 127.00 & 195.87 & 176.67 \\
\hline 3 & $\mathrm{~F}_{1}$ & 92.20 & 73.67 & 132.13 & 127.27 & 203.87 & 176.80 \\
\hline 4 & $\mathrm{~F}_{2}$ & $88.57^{*}$ & $60.15^{*}$ & $129.18^{*}$ & $97.60^{*}$ & 188.55 & 141.75 \\
\hline 5 & $\mathrm{~B}_{1}$ & 92.20 & 68.83 & 131.50 & 121.30 & $208.10^{*}$ & $178.03^{*}$ \\
\hline 6 & $\mathrm{~B}_{2}$ & 95.20 & 74.13 & 133.77 & 128.03 & 196.73 & 172.00 \\
\hline \multicolumn{2}{|c|}{ Mean } & 91.78 & 68.88 & 131.86 & 120.3 & 198.31 & 170.41 \\
\hline \multicolumn{2}{|c|}{$\mathrm{SE} \pm$} & 1.16 & 0.49 & 0.94 & 0.93 & 2.72 & 3.85 \\
\hline \multicolumn{2}{|c|}{$\mathrm{CD}$ at $5 \%$} & 3.65 & 1.56 & 2.97 & 2.92 & 8.59 & 12.14 \\
\hline
\end{tabular}

* Significant at $5 \%$ level; ** Significant at $1 \%$ level.

Table 1. Contd.....

\begin{tabular}{|c|c|c|c|c|c|c|c|c|c|}
\hline \multirow{2}{*}{$\begin{array}{l}\text { Sr. } \\
\text { No }\end{array}$} & \multirow{2}{*}{ Generations } & \multicolumn{2}{|c|}{ Harvest Index (\%) } & \multicolumn{2}{|c|}{$\begin{array}{l}\text { 1000 grain weight } \\
\text { (g) }\end{array}$} & \multicolumn{2}{|c|}{$\begin{array}{l}\text { DF/Plant at maturity } \\
\text { (g/plant) }\end{array}$} & \multicolumn{2}{|c|}{$\begin{array}{l}\text { Grain yield/Plant } \\
\text { (g/plant) }\end{array}$} \\
\hline & & $\begin{array}{l}\text { Non } \\
\text { stress }\end{array}$ & $\begin{array}{l}\text { Moisture } \\
\text { stress }\end{array}$ & $\begin{array}{l}\text { Non } \\
\text { stress }\end{array}$ & $\begin{array}{l}\text { Moisture } \\
\text { stress }\end{array}$ & $\begin{array}{l}\text { Non } \\
\text { stress }\end{array}$ & $\begin{array}{l}\text { Moisture } \\
\text { stress }\end{array}$ & $\begin{array}{l}\text { Non } \\
\text { stress }\end{array}$ & $\begin{array}{l}\text { Moisture } \\
\text { stress }\end{array}$ \\
\hline 1 & $\mathrm{P}_{1}$ & $30.80^{*}$ & $27.69^{*}$ & 23.65 & 20.68 & 89.93 & $85.60^{*}$ & $56.93^{*}$ & $52.27^{*}$ \\
\hline 2 & $\mathrm{P}_{2}$ & 27.93 & 24.86 & $28.63^{*}$ & $24.93^{*}$ & 72.00 & 68.73 & 46.87 & 24.33 \\
\hline 3 & $\mathrm{~F}_{1}$ & 36.37 & 32.10 & 26.49 & 23.19 & 85.53 & 78.33 & 61.33 & 47.13 \\
\hline 4 & $\mathrm{~F}_{2}$ & 30.08 & 26.65 & $28.85^{*}$ & $26.49 *$ & 71.12 & 63.95 & $45 \cdot 33$ & 28.92 \\
\hline 5 & $\mathrm{~B}_{1}$ & $36.92^{*}$ & $33.06^{*}$ & $25 \cdot 34$ & 22.04 & 89.17 & $78.67^{*}$ & $62.40^{*}$ & $48.30^{*}$ \\
\hline 6 & $\mathrm{~B}_{2}$ & 29.28 & 28.18 & 27.09 & 24.06 & 76.50 & 71.57 & 49.00 & 40.27 \\
\hline \multicolumn{2}{|c|}{ Mean } & 31.90 & 28.76 & 26.67 & $\mathbf{2 3 . 5 7}$ & 53.02 & 42.28 & 41.13 & 40.20 \\
\hline \multicolumn{2}{|c|}{$\mathrm{SE}_{ \pm}$} & 0.91 & 0.54 & 0.36 & 0.57 & 13.47 & 4.62 & 9.01 & 1.57 \\
\hline \multicolumn{2}{|c|}{$\mathrm{CD}$ at $5 \%$} & 2.86 & 1.69 & 1.12 & 1.79 & 42.43 & 14.54 & 28.38 & 4.96 \\
\hline
\end{tabular}

* Significant at $5 \%$ level; ${ }^{* *}$ Significant at $1 \%$ level.

\section{Days to 50 per cent flowering}

The mean number of days required for 50 per cent flowering ranged between 87.53 and 95.20 days with a mean of 91.78 days under non stress condition and 60.15 to 74.13 days with a mean of 68.88 days under moisture stress condition. Parent $\mathrm{P}_{1}$ recorded earliness for this trait 87.53 days for non stress condition Among the different segregating generations, the $F_{2}$ generation recorded lower days for 50 per cent flowering (88.57 days) under non stress condition. The drought tolerant parent $\mathrm{P}_{1}$ (RSV 1237) and $F_{2}$ recorded earliness for days to
50 per cent flowering (87.53 and 60.15 days) under non stress and moisture stress condition, respectively.

For the non stress condition, the scaling tests viz., 'A' $\left(4.67^{* *}\right)$, 'B' $\left(3.20^{* *}\right)$ 'C' $\left(-12.67^{* *}\right)$ and 'D' $\left(-10.27^{* *}\right)$ were found significant indicating presence of epistasis or non-allelic interactions (Table 2). Similarly, the joint scaling test was also significant which confirmed the presence of nonallelic interactions and hence additive-dominance model is not adequate. The genetic parameter ' $\mathrm{d}$ ' $(-3.00)$ was negatively significant and ' $h$ ' (21.47) were positively significant (Table 3). However, 
the parameter ' $h$ ' (21.47) had higher magnitude as compared to 'd' (-3.00). Among the interaction components, 'i' (20.53) was positively significant while 'j' (0.73) was non-significant and 'l'
(-28.40) components was negatively significant, the genetic parameters ' $h$ ' and 'l' recorded opposite signs indicating duplicate type of interaction.

Table 2. Estimates of individual scaling tests and Cavelli's (1952) $\chi 2$ values for different characters under non stress and moisture stress conditions in rabi sorghum.

\begin{tabular}{|c|c|c|c|c|}
\hline Sr. No. & Name of characters & Scaling tests & Non stress condition & Moisture stress condition \\
\hline \multirow[t]{5}{*}{1} & Days to 50\% flowering & A & $4.67^{* *}$ & -1.40 \\
\hline & & B & $3 \cdot 20^{* *}$ & $3.53^{* *}$ \\
\hline & & $\mathrm{C}$ & $-12.67^{* *}$ & $-43.20^{* *}$ \\
\hline & & $\mathrm{D}$ & $-10.27^{* *}$ & $-22.67^{* *}$ \\
\hline & Chi square $\left(\mathbf{X}^{2}\right)$ & & $53.84^{* *}$ & $713 \cdot 30^{* *}$ \\
\hline \multirow[t]{5}{*}{2} & Days to physiological maturity & A & $2.27^{* *}$ & $-5.27^{*}$ \\
\hline & & B & -0.60 & 1.80 \\
\hline & & $\mathrm{C}$ & $-12.13^{* *}$ & $-111.73^{* *}$ \\
\hline & & $\mathrm{D}$ & $-6.90^{* *}$ & $-54.13^{* *}$ \\
\hline & Chi square $\left(\mathbf{X}^{2}\right)$ & & $54.13^{* *}$ & 2132. $77^{* *}$ \\
\hline \multirow[t]{5}{*}{3} & Plant height & A & $15.60^{* *}$ & 2.07 \\
\hline & & B & -6.27 & -9.47 \\
\hline & & $\mathrm{C}$ & $-46.13^{* *}$ & $-140.47^{* *}$ \\
\hline & & $\mathrm{D}$ & $-27.73^{* *}$ & $-66.53^{* *}$ \\
\hline & Chi square ( $\left.\mathbf{X}^{2}\right)$ & & $68.25^{* *}$ & $123.17^{* *}$ \\
\hline \multirow[t]{5}{*}{4} & 1000 Grain Weight & A & 0.53 & 0.21 \\
\hline & & B & -0.95 & 0.01 \\
\hline & & $\mathrm{C}$ & $10.12^{* *}$ & $13.98^{* *}$ \\
\hline & & $\mathrm{D}$ & $5.27^{* *}$ & $6.88^{* *}$ \\
\hline & Chi square $\left(\mathrm{X}^{2}\right)$ & & $13 \cdot 70^{* *}$ & 22.10** \\
\hline \multirow[t]{5}{*}{5} & Harvest index & A & $6.67^{* * *}$ & $6.32^{* *}$ \\
\hline & & B & $-5.73^{*}$ & -0.60 \\
\hline & & $\mathrm{C}$ & $-11.17^{*}$ & $-10.16^{*}$ \\
\hline & & $\mathrm{D}$ & $-6.06^{* *}$ & $-7.94^{* *}$ \\
\hline & Chi square $\left(\mathbf{X}^{2}\right)$ & & $27.87^{* *}$ & $35.27^{* *}$ \\
\hline \multirow[t]{5}{*}{6} & Dry fodder/plant & A & 2.87 & -6.60 \\
\hline & & B & -4.53 & -3.93 \\
\hline & & $\mathrm{C}$ & $-48.53^{*}$ & $-55.20^{* *}$ \\
\hline & & $\mathrm{D}$ & $-23.43^{*}$ & $-22.33^{*}$ \\
\hline & Chi square $\left(\mathbf{X}^{2}\right)$ & & $6.41^{* *}$ & 7.95 \\
\hline \multirow[t]{5}{*}{7} & Grain yield /plant & A & 6.53 & -2.80 \\
\hline & & B & $-10.20^{*}$ & $9.07^{* *}$ \\
\hline & & $\mathrm{C}$ & $-45.13^{* *}$ & $-55.20^{* *}$ \\
\hline & & $\mathrm{D}$ & $-20.73^{* *}$ & $-30.73^{* *}$ \\
\hline & Chi square $\left(\mathbf{X}^{2}\right)$ & & $61.47^{* *}$ & $70.29^{* *}$ \\
\hline
\end{tabular}

* Significant at $5 \%$ level; ${ }^{* *}$ Significant at $1 \%$ level.

In moisture stress condition, scaling tests ' $\mathrm{B}$ ' $\left(3.53^{* *}\right)$ 'C' $\left(-43.20^{* *}\right)$ and ' $\mathrm{D}$ ' $\left(-22.67^{* *}\right)$ were found significant while scaling test 'A' $(-1.40)$ was non-significant indicating the presence of epistasis or non allelic interactions. The joint scaling test was also significant which confirmed the presence of non-allelic interactions and hence additive-dominance model is not adequate. The genetic parameter ' $d$ ' $(-5.30)$ was negatively significant and ' $h$ ' (50.77) were positively significant. However, the parameter ' $h$ ' (50.77) had higher magnitude as compared to 'd' (-5.30). Among the interaction components, 'i' (45.33) was positively significant while 'j' (-2.47) was negatively non-significant and ' $\mathrm{l}$ ' (-47.47) components was negatively significant, the genetic parameters ' $h$ ' and ' $\mathrm{l}$ ' recorded opposite signs indicating duplicate type of interaction. This finding confirms the earlier reports of Gaikwad et al. (2002), Thul (2007) and Patil (2008). 
Table 3. Estimates of genetic effects for yield and yield contributing characters in Cross RSV1237 X RSV 1703 under non stress condition in rabi sorghum.

\begin{tabular}{llllllll}
\hline $\begin{array}{l}\text { Sr. } \\
\text { No. }\end{array}$ & Name of character & $\mathbf{M}$ & $\mathbf{d}$ & $\mathbf{h}$ & $\mathbf{i}$ & $\mathbf{j}$ & $\mathbf{l}$ \\
\hline 1 & Days to 50\% flowering & $88.57^{* *}$ & $-3.00^{*}$ & $21.47^{* *}$ & $20.53^{* *}$ & 0.73 & $-28.40^{* *}$ \\
& & $(0.67)$ & $(0.70)$ & $(3.05)$ & $(3.04)$ & $(0.72)$ & $(3.94)$ \\
2 & Days to Physiological maturity & $129.18^{* *}$ & $-2.27^{* *}$ & $13.63^{* *}$ & $13.80^{* *}$ & $1.43^{*}$ & $-15.47^{* *}$ \\
& & $(0.55)$ & $(0.33)$ & $(2.36)$ & $(2.28)$ & $(0.40)$ & $(2.82)$ \\
3 & Plant height (cm) & $188.55^{* *}$ & $11.37^{* *}$ & $63.03^{* *}$ & $55.47^{* *}$ & $10.93^{*}$ & $-64.80^{* *}$ \\
& & $(1.34)^{* *}$ & $(3.51)$ & $(9.59)$ & $(8.83)$ & $(4.63)$ & $(16.69)$ \\
4 & \multirow{2}{*}{ 10oo grain weight (g) } & $28.85^{* *}$ & $-1.75^{* *}$ & $-10.18^{* *}$ & $-10.53^{* *}$ & 0.74 & $10.95^{* *}$ \\
& & $(0.69)$ & $(0.59)$ & $(3.11)$ & $(3.01)$ & $(0.89)$ & $(3.96)$ \\
5 & Harvest index (\%) & $30.08^{* *}$ & $7.64^{* *}$ & $19.11^{* *}$ & $12.11^{* *}$ & $6.20^{* *}$ & $-13.05^{* *}$ \\
& & $(0.80)$ & $(1.22)$ & $(4.23)$ & $(4.03)$ & $(1.45)$ & $(6.37)$ \\
6 & \multirow{2}{*}{ Dry fodder yield /plant } & $71.12^{* *}$ & $12.67^{* *}$ & $51.43^{*}$ & $46.87^{*}$ & 3.70 & -45.20 \\
7 & & $(5.11)$ & $(2.80)$ & $(21.49)$ & $(21.19)$ & $(3.41)$ & $(24.39)$ \\
& & $45.33^{* *}$ & $13.40^{* *}$ & $50.90^{* *}$ & $41.47^{* *}$ & $8.37^{* *}$ & $-37.80^{* *}$ \\
\hline
\end{tabular}

* Significant at $5 \%$ level; ** Significant at $1 \%$ level; Figures in parentheses indicate standard error.

Table 4. Estimates of genetic effects for yield and yield contributing characters in Cross RSV1237 X RSV 1703 moisture stress condition in rabi sorghum.

\begin{tabular}{|c|c|c|c|c|c|c|c|}
\hline $\begin{array}{l}\text { Sr. } \\
\text { No. }\end{array}$ & Name of character & $\mathbf{m}$ & d & h & $\mathbf{i}$ & $\mathbf{j}$ & 1 \\
\hline 1 & Days to 50\% flowering & $\begin{array}{l}60.15^{* *} \\
(0.37)\end{array}$ & $\begin{array}{l}-5.30^{* *} \\
(0.89)\end{array}$ & $\begin{array}{l}50.77^{* *} \\
(2.37)\end{array}$ & $\begin{array}{l}45 \cdot 33^{* *} \\
(2.32)\end{array}$ & $\begin{array}{l}-2.47^{*} \\
(0.96)\end{array}$ & $\begin{array}{l}-47.47^{* *} \\
(3.98)\end{array}$ \\
\hline 2 & $\begin{array}{l}\text { Days to Physiological } \\
\text { maturity }\end{array}$ & $\begin{array}{l}97.60^{* *} \\
(0.57)\end{array}$ & $\begin{array}{l}-6.73^{* *} \\
(1.32)\end{array}$ & $\begin{array}{l}111.73^{* *} \\
(3.52)\end{array}$ & $\begin{array}{l}108.27^{* *} \\
(3.49)\end{array}$ & $\begin{array}{l}-3.53^{*} \\
(1.36)\end{array}$ & $\begin{array}{l}-104.80^{* *} \\
(5.85)\end{array}$ \\
\hline 3 & Plant Height $(\mathrm{cm})$ & $\begin{array}{l}141.75^{* *} \\
(2.78)\end{array}$ & $\begin{array}{l}6.03 \\
(5.41)\end{array}$ & $\begin{array}{l}132.93^{* *} \\
(15.89)\end{array}$ & $\begin{array}{l}133.07^{* *} \\
(15 \cdot 51)\end{array}$ & $\begin{array}{l}5 \cdot 77 \\
(5 \cdot 77)\end{array}$ & $\begin{array}{l}-125.67^{* *} \\
(25.28)\end{array}$ \\
\hline 4 & 1000 grain weight $(\mathrm{g})$ & $\begin{array}{l}26.49^{* *} \\
(0.69)\end{array}$ & $\begin{array}{l}-2.02^{* *} \\
(0.74)\end{array}$ & $\begin{array}{l}-13 \cdot 39^{* *} \\
(3.22)\end{array}$ & $\begin{array}{l}-13.76^{* *} \\
(3.13)\end{array}$ & $\begin{array}{l}0.10 \\
(1.00)\end{array}$ & $\begin{array}{l}13 \cdot 54^{* *} \\
(4 \cdot 33)\end{array}$ \\
\hline 5 & Harvest Index (\%) & $\begin{array}{l}26.65^{* *} \\
(0.87)\end{array}$ & $\begin{array}{l}4.88^{* *} \\
(0.80)\end{array}$ & $\begin{array}{l}21.70^{* *} \\
(3.92)\end{array}$ & $\begin{array}{l}15.87^{* *} \\
(3.82)\end{array}$ & $\begin{array}{l}3.46^{* *} \\
(1.03)\end{array}$ & $\begin{array}{l}-21.59^{* *} \\
(5.03)\end{array}$ \\
\hline 6 & Dry fodder yield per plant & $\begin{array}{l}63.95^{* *} \\
(5.09)\end{array}$ & $\begin{array}{l}7.10^{*} \\
(3.32)\end{array}$ & $\begin{array}{l}45.83^{*} \\
(21.57)\end{array}$ & $\begin{array}{l}44.67^{*} \\
(21.40)\end{array}$ & $\begin{array}{l}-1.33 \\
(3.64)\end{array}$ & $\begin{array}{l}-34.13 \\
(24.90)\end{array}$ \\
\hline 7 & Grain Yield/Plant (g) & $\begin{array}{l}28.92^{* *} \\
(1.88)\end{array}$ & $\begin{array}{l}8.03^{* *} \\
(1.33)\end{array}$ & $\begin{array}{l}70.30^{* *} \\
(8.16)\end{array}$ & $\begin{array}{l}61.47^{* * *} \\
(7.98)\end{array}$ & $\begin{array}{l}-5.93^{* *} \\
(1.73)\end{array}$ & $\begin{array}{l}-67.73^{* *} \\
(9.85)\end{array}$ \\
\hline
\end{tabular}

* Significant at $5 \%$ level; ** Significant at $1 \%$ level; Figures in parentheses indicate standard error.

\section{Days to physiological maturity}

The parent $P_{1}$ (RSV 1237) recorded significantly lowest days (128.60 and 120.60 days) for physiological maturity under non stress and moisture stress condition, respectively. While amongst different generations, the F2 generation recorded lower days for physiological maturity (129.18 and 97.60 days) under non stress and moisture stress condition, respectively. The mean performance for days to physiological maturity ranged between 128.60 to 136 .00 days with 131.86 days under non stress condition and 97.60 to 128.03 days with a mean of 120.3 days under moisture stress condition.
In non stress condition, the scaling tests ' $\mathrm{A}$ ' $\left(2.27^{* *}\right)$, 'C' $\left(-12.13^{* *}\right)$ and ' $D$ ' $\left(-6.90^{* *}\right)$ were found significant while 'B' (-0.60) was non-significant indicating presence of epistasis or non-allelic interactions. The joint scaling test was found highly significant indicating the presence of epistasis and hence additive-dominance model is inadequate. The genetic parameter ' $\mathrm{d}$ ' $(-2.27)$ was negatively significant and ' $h$ ' (13.63) were positively significant. However, the parameter ' $h$ ' (13.63) had higher magnitude as compared to 'd' (-2.27). Among the interaction components ' $\mathrm{i}$ ' (13.80) and ' $\mathrm{j}$ ' (1.43) was positively significant and 'l' (-15.47) component was negatively significant, the genetic parameters ' $h$ ' and 'l' recorded opposite 
signs indicating duplicate type of interaction. This finding confirms the earlier reports of Premlatha et al. (2006), Kulkarni et al. (2006), Thul (2007) and Patil (2008).

In moisture stress condition, the scaling tests ' $\mathrm{A}$ ' $\left(-5.27^{*}\right)$, 'C' $\left(-111.73^{* *}\right)$ and 'D' $\left(-54.13^{* *}\right)$ were found significant while scaling test ' $\mathrm{B}$ ' $(-1.80)$ was found non-significant indicating the presence of epistasis or non allelic interactions. The joint scaling test was also significant which confirmed the presence of non-allelic interactions and hence additive-dominance model is not adequate. The genetic parameter ' $d$ ' (-6.73) was negatively significant and ' $h$ ' (111.73) was positively significant (Table 4). However, the parameter ' $h$ ' (111.73) had higher magnitude as compared to ' $d$ ' (-6.73). Among the interaction components ' $i$ ' (108.27) was positively significant and 'j' (-3.53) was negatively significant and ' $\mathrm{l}$ ' (-104.80) component was negatively significant, the genetic parameters ' $h$ ' and ' $l$ ' recorded opposite signs indicating duplicate type of interaction. The important of additive gene action for this trait was noticed by Rafiq et al. (2002) while non additive gene action was reported by Khandelwal et al. (2006), Kulkarni et al. (2006) and Udutha (2008).

\section{Plant height (cm)}

The mean plant height in parents ranges from $195.87 \mathrm{~cm}$ in P2 (RSV 1703) to $196.73 \mathrm{~cm}$ in $\mathrm{P} 1$ (RSV 1237) and $176.67 \mathrm{~cm}$ in $\mathrm{P} 2$ (RSV 1703) to $177.20 \mathrm{~cm}$ in P1 (RSV 1237) under non stress and moisture stress condition, respectively. Among the parents, P1 recorded significantly higher plant height $(196.73$ and $177.20 \mathrm{~cm})$ under non stress and moisture stress conditions, respectively. In case of different generations, B1 generation recorded significantly higher plant height (208.10 $\mathrm{cm}$ and $178.03 \mathrm{~cm}$ ) under non stress and moisture stress condition, respectively (Table 1 ).

In non stress condition, the scaling tests ' $A$ ' $\left(15.60^{* *}\right)$, 'C' $\left(-46.13^{* *}\right)$ and ' $\mathrm{D}$ ' $\left(-27.73^{* *}\right)$ were found significant while 'B' (-6.27) was nonsignificant indicating presence of epistasis or nonallelic interactions.The genetic parameter ' $\mathrm{d}$ ' (11.37) and 'h' (63.03) were positively significant. However, the parameter ' $h$ ' (63.03) had greater magnitude as compared to 'd' (11.37). Among the interaction components 'i’ (55.47) and 'j' (10.93) was positively significant and ' $\mathrm{l}$ ' (-64.80) component was negatively significant, the genetic parameters ' $h$ ' and ' $l$ ' recorded opposite signs indicating duplicate type of interaction.

In moisture stress condition, the scaling tests ' $\mathrm{C}$ ' $\left(-140.47^{* *}\right)$ and 'D' $\left(-66.53^{* *}\right)$ were found significant while scaling test 'A' (2.07) and 'B' $(-9.47)$ was non-significant for plant height indicating the presence of epistasis or non-allelic interactions. The joint scaling test was also significant which confirmed the presence of nonallelic interactions and hence additive-dominance model is not adequate. The genetic parameter ' $\mathrm{d}$ ' (6.03)was positively non-significant and ' $h$ ' (132.93) was positively significant. However, the parameter ' $h$ ' (132.93) had greater magnitude as compared to ' $\mathrm{d}$ ' (6.03). Among the interaction components 'i' (133.07) was positively significant and 'j' (5.77) was positively non-significant and 'l' $(-125.67)$ component was negatively significant, the genetic parameters ' $h$ ' and 'l' recorded opposite signs indicating duplicate type of interaction. This finding confirms the earlier reports of Ravindrababu and Pathak (2001) and Premlatha et al. (2006).

\section{Harvest index (\%)}

The genotype $\mathrm{P}_{1}$ (RSV 1237) recorded more harvest index (30.80 and $27.69 \%$ ) than P2 (IS-6427) under non stress and moisture stress condition, respectively. In case of different generations, the $\mathrm{B}_{1}$ generation recorded significantly more harvest index (35.92 and $33.06 \%)$ under non stress and moisture stress condition, respectively (Table 1 ).

In non stress condition, the scaling tests, ' $A$ ' $\left(6.67^{* *}\right)$ and 'B' $\left(-5.73^{*}\right)$ 'C' $\left(-11.17^{*}\right)$ and ' $\mathrm{D}$ ' $\left(-6.06^{* *}\right)$ were found significant which indicating presence of epistasis. The genetic parameter ' $d$ ' (7.64) and ' $h$ ' (19.11) were positively significant. However, the parameter ' $h$ ' (19.11) had greater magnitude as compared to 'd' (7.64). Among the interaction components ' $\mathrm{i}$ ' (12.11) and ' $\mathrm{j}$ ' (6.20) was positively significant and ' $\mathrm{l}$ ' $(-13.20)$ component was negatively significant, the genetic parameters ' $h$ ' and ' $l$ ' recorded opposite signs indicating duplicate type of interaction. The importance of additive $x$ additive (i) gene interaction effects was also reported by Lad (2009) and Karande (2015). 
In moisture stress condition, the scaling tests ' $\mathrm{A}$ ' (6.32) and 'C' $\left(-10.16^{*}\right)$ and 'D' $\left(-7.94^{* *}\right)$ were found significant while scaling test ' $\mathrm{B}$ ' $(-0.60)$ was non-significant for harvest index indicating the presence of epistasis. The joint scaling test was also significant which confirmed the presence of nonallelic interactions and hence additive-dominance model is not adequate. The genetic parameter ' $\mathrm{d}$ ' (4.88) and ' $h$ ' (21.70) were positively significant. However, the parameter ' $h$ ' (21.70) had greater magnitude as compared to 'd' (4.48). Among the interaction components 'i' (15.87) and 'j' (3.46) was positively significant and 'l' (-21.59) component was negatively significant, the genetic parameters ' $h$ ' and ' $\mathrm{l}$ ' recorded opposite signs indicating duplicate type of interaction. These results are in conformity with the earlier finding of Dhole (2004), Khandelwal et al. (2006), Kshirsagar (2007) and Karande (2015).

\section{0 grain weight $(\mathrm{g})$}

Among the parents, the genotype P2 (RSV 1703) recorded higher 1000 grain weight (28.63 and 24.93 g) under non stress and moisture stress condition, respectively. In case of different generations, the F2 generation recorded significantly higher 1000 grain weight (28.85 and $26.49 \mathrm{~g}$ ) under non stress and moisture stress condition, respectively. The mean performance for 1000 grain weight ranged between $23.65 \mathrm{~g}$ to 28.85 g with mean 26.67 and 20.68 g to 26.49 g with mean 23.57 under non stress and moisture stress condition, respectively (Table 1 ).

In non stress condition, the scaling tests, ' $\mathrm{C}$ ' $\left(10.12^{* *}\right)$ and ' $\mathrm{D}$ ' $\left(5.27^{* *}\right)$ were found significant while 'A' (0.53) and 'B' (-0.95) was non-significant indicating presence of epistasis or non allelic interactions (Table 2). The genetic parameter ' $d$ ' $(-1.75)$ and ' $h$ ' (-10.18) were negatively significant. However, the parameter ' $h$ ' $(-10.18)$ had greater magnitude as compared to 'd' (-1.75) (Table 3). Among the interaction components ' $\mathrm{i}$ ' $(-10.53)$ was negatively significant and 'j' (0.74) and 'l' (10.95) component was positively significant, the genetic parameters ' $h$ ' and ' $l$ ' recorded opposite signs indicating duplicate type of interaction.

In moisture stress condition, the scaling tests ' $\mathrm{C}$ ' $\left(13.98^{* *}\right)$ and ' $\mathrm{D}$ ' $\left(6.88^{* *}\right)$ were found significant while scaling test 'A' (0.21) and 'B' (0.01) was non significant indicating the presence of epistasis or non-allelic interactions. The joint scaling test was also significant which confirmed the presence of non-allelic interactions and hence additivedominance model is not adequate. The genetic parameter 'd' (-2.02) and ' $h$ ' (-13.39) were negatively significant. However, the parameter ' $h$ ' $(-13.39)$ had greater magnitude as compared to 'd' (-2.02). Among the interaction components ' $\mathrm{i}$ ' $(-13.76)$ was negatively significant and 'j' (0.10) was positively non significant and 'l' (13.54) component was positively significant, the genetic parameters ' $h$ ' and ' $l$ ' recorded opposite signs indicating duplicate type of interaction.

The importance of non additive gene action for the 1000 grain weight was noticed by Chaudhary et al. (2006) and Solanki et al. (2007).

\section{Dry fodder yield/plant (g)}

In case of dry fodder yield per plant, the genotype P1 (RSV 1237) recorded significantly higher dry fodder yield (89.93 and 85.60 g) under non stress and moisture stress condition, respectively. Amongst the different generations, B1 generation recorded significantly higher dry fodder yield (89.17 and $78.67 \mathrm{~g}$ ) under non stress and moisture stress condition, respectively.

Innon stress condition, the scaling tests, ' $\mathrm{C}$ ' $\left(-48.53^{* *}\right)$ was found significant while 'A' (2.87), 'B' (-4.53) and 'D' (-23.43) was non significant which indicating presence of epistasis or non allelic interactions. The genetic parameter 'd' (12.67) and ' $h$ ' (51.43) were positively significant. However, the parameter ' $h$ ' (51.43) had greater magnitude as compared to ' $\mathrm{d}$ ' (12.67).Among the interaction components 'i' (46.87) was positively significant and 'j' (3.70) was positively non significant and 'l' $(-45.20)$ component was negatively non significant, the genetic parameters ' $h$ ' and 'l' recorded opposite signs indicating duplicate type of interaction.

In moisture stress condition, the scaling tests ' $C$ ' $\left(-55.20^{* *}\right)$ and ' $D$ ' $\left(-22.33^{*}\right)$ were found significant while scaling test 'A' (-6.60) and 'B' (-3.93) were non-significant indicating the presence of epistasis or non-allelic interactions. The genetic parameter 'd' (7.10) and ' $h$ ' (45.83) were positively significant. However, the parameter ' $h$ ' (45.83) had greater magnitude as compared to 'd' (7.10). Among the 
interaction components 'i' (44.67) was positively significant and 'j' (-1.33) was negatively non significant and ' $\mathrm{l}$ ' (-34.13) component was negatively non significant, the genetic parameters ' $h$ ' and 'l' recorded opposite signs indicating duplicate type of interaction (Table 4).

The importance of non additive gene action for this trait was noticed byKshirsagar (2007) while Baskheti and Bhatt (2005) reported additive $\mathrm{x}$ dominance gene action for this trait.

\section{Grain yield per plant (g)}

In case of grain yield per plant, the genotype P1 (RSV 1237) recorded higher grain yield (56.93 g and 52.27 g) under non stress and moisture stress condition. Among the different segregating generations, the $\mathrm{B} 1$ generation recorded significantly higher grain yield (62.40 $\mathrm{g}$ and 48.30 g) followed by F1 generation (61.33 g and $47.13 \mathrm{~g}$ ) under non stress and moisture stress condition, respectively. Grain yield/plant was ranged between $45.33 \mathrm{~g}$ to 62.40 with mean $41.13 \mathrm{~g}$ and $24.33 \mathrm{~g}$ to $52.27 \mathrm{~g}$ with mean $40.20 \mathrm{~g}$, under non stress and moisture stress condition, respectively (Table 1 ).

In non stress condition, the scaling tests ' $\mathrm{B}$ ' $\left(-10.20^{*}\right)$ 'C' $\left(-45.13^{* *}\right)$ and 'D' $\left(-20.73^{* *}\right)$ was found significant while 'A' (6.53) was nonsignificant indicating the presence of epistasis or non allelic interactions (Table 2). The genetic parameter 'd' (13.40) and ' $h$ ' (50.90) were positively significant. However, the parameter ' $h$ ' (50.90) had greater magnitude as compared to ' $\mathrm{d}$ ' (13.40). Among the interaction components ' $i$ ' (41.47) and ' $\mathrm{j}$ ' (8.37)was positively significant and 'l' (-37.80) component was negatively significant, the genetic parameters ' $h$ ' and 'l' recorded opposite signs indicating duplicate type of interaction.

In moisture stress condition, the scaling tests ' $\mathrm{B}$ ' $\left(9.07^{* *}\right)$ and 'C' $\left(-55.20^{* *}\right)$ and 'D' $\left(-30.73^{* *}\right)$ were found significant while scaling test ' $A$ ' $(-2.80)$ was non-significant indicating the presence of epistasis or non-allelic interactions. The joint scaling test was also significant which confirmed the presence of non-allelic interactions and hence additivedominance model is not adequate. The genetic parameter ' $d$ ' (8.03) and ' $h$ ' (70.30) were positively significant. However, the parameter ' $h$ ' (70.30) had greater magnitude as compared to ' $d$ ' (8.03).
Among the interaction components ' $i$ ' (61.47) was positively significant and ' $\mathrm{j}$ ' $(-5.93)$ was negatively significant and ' $\mathrm{l}$ ' (-67.73) component was negatively significant, the genetic parameters ' $h$ ' and 'l' recorded opposite signs indicating duplicate type of interaction (Table 4). The similar results were reported earlier by Narain et al. (2007), Thul (2007), Lad et al. (2009), Prakash et al. (2010), Mahdy et al. (2011), Tariq et al. (2012) and Prabhakar et al. (2013).

\section{Conflict of interest statement}

Authors declare that they have no conflict of interest.

\section{References}

Anderson, V.L., Kempthrone, O., 1954. A method for the study of quantitative inheritance. Genetics 39, 883-898.

Baskheti, D. C., Bhatt, A., 2005. Genetic analysis for yield and yield components in seven crosses among sorghum (Sorghum bicolor) x Sudan grass ( Sorghum sudanense). Int. J. Agri. Sci. 1(1), 7-10.

Chaudhary, S. B., Patil, J. V., Thombare, B. B., Kulkarni, V. M., 2006. Selection of parents based on combining ability studies in sorghum [Sorghum bicolor (L.) Moench]. Ann. Plant Physiol. 20(1), 95-97.

Dhole, V.J., 2004. Genetic analysis and multiple trait selection indices based on selection methods in rabi sorghum. Ph.D. Thesis submitted to MPKV, Rahuri.

FAO, 2013. Production Yearbook. Food and Agricutlure Organization, Rome, Italy.

Gaikwad, N. J., Thete, R. Y., Kanawade, D. G., Patil, J. V., Kute, N. S., 2002. Selection of parents based on combining ability in sorghum. Indian J. Agric. Res. 36(2), 141-144.

Gamble, E. E., 1962. Gene effects of corn (Zea mays L.) I. Separation and relative importance of gene effects for yield. Can. J. Plant Sci. 42, 339-348.

Hayman, B. I., 1958. Separation of epistatic from additive and dominance variation in generation means. Heredity 12, 371-390.

Kanawade, D.G., Deshmukh, R. B., Kute, N. S., Patil, J.V., Dhonde, S. R., 2001. Combining ability studies in sorghum [Sorghum bicolor (L.) Moench]. Indian J. Agric. Res. 35(1), 56-59. 
Karande S. P., 2015. Genetics of traits associated with shootfly and drought resistance in rabi Sorghum. Ph.D. (Agri.) Thesis submitted to MPKV, Rahuri.

Khot, K. B., 2008. Generation mean analysis and molecular assay of yield and yield components for drought tolerance in rabi Sorghum. Ph.D. (Agri.) Thesis submitted to MPKV, Rahuri.

Kshirsagar, R.M., 2007. Heterosis, combining ability and stability studies in grain sorghum [Sorghum bicolor (L.) Moench]. Ph.D. Thesis submitted to Navsari Agricultural University, Navsari.

Kulkarni, V., Patil, M. S., Salimath, P. M., 2006. Combining ability studies for shootfly resistance in rabi sorghum. Crop Res. 7 (1), 324-326.

Lad, D. B., 2009. Genetics of traits associated with shootfly and drought resistance in rabi sorghum. Ph.D. (Agri.) Thesis submitted to MPKV, Rahuri.

Mather, K., 1949. Biometrical Genetics. Mathue and Co., London, pp. 12-24.

Narain, V., Sing, P. K., Kumar, N., Sing, V. S., 2007. Gene effects for grain yield and related traits in sorghum (Sorghum bicolor (L.) Moench). Indian J. Genet. Plant Breed. 67(1), 34-36.

Prabhakar, Elangovan, M., Bahadure, D. M., 2013. Combining ability of new parental lines for flowering, maturity and grain yield in rabi sorghum. Elect. J. Plant Breed. 4(3), 1214-1218.

Prakash, R., Ganeshmurty, K., Nirmalkumar, A., Nagarajan, P., 2010. Combining ability for fodder yield and its components in sorghum (Sorghum bicolor (L.). Elect. J. Plant Breed. 1 (2), 140-144.

Premalatha, N., Kumaravadivel, N., Veerabadhiran,
P., 2006. Heterosis and combining ability for grain yield and its components in sorghum [Sorghum bicolor (L.) Moench]. Indian J. Genet. 66 (2), 123-126.

Rafiq, S.M., Thete, R.Y., Madhusudhana, R., Umakanth, A.V., 2002. Combining ability studies for grain yield and its components in post rainy season where sorghum grown in medium deep and shallow soils. Int. Sorghum Millet News Lett. 43, 33-37.

Rajguru, A.B., Kashid., N.V., Kamble, M.S., Rasal, P.N., Gosavi, A.B., 2005. Gene action and heritability studies in rabi sorghum [Sorghum bicolor (L.) Moench]. J. Maharashtra Agric. Univ. 30(3), 367-368.

Ravindrababu, Y., Pathak, A.R., 2001. Gene effects for yield and shootfly resistance in sorghum. GAU Res. J. 26(1), 27-29.

Solanki, B.G., Patel, D.M., Patel P.B., Desai, R.T., 2007. Combining ability analysis in sorghum [Sorghum bicolor (L) Moench] for yield and its attributing traits. Crop Res. Hisar 33 (1/3), 187-191.

Tariq, A. S., Zahid, A., Ghulam, S.K., Iqbal, M. S., 2012. Heterosis and combing ability for quantitative traits in fodder sorghum (Sorghum bicolor L.). Elect. J. Plant Breed. 3(2), 775-781.

Thul, A.V., 2007. Genetics of traits associated with shootfly and drought tolerance in Rabi sorghum [Sorghum bicolor (L.) Moench]. Ph.D. Thesis submitted to M.P.K.V., Rahuri.

Udutha, J. V., 2008. Genetic studies of yield and its components using male sterile lines in sorghum [Sorghum bicolor (L.) Moench]. Ph.D. Thesis. Navsari Agricultural University, Navsari.

\section{How to cite this article:}

Tambe, S. A., Kusalkar, D. V., Shinde, G. S., Shinde, M. S., 2019. Inheritance of morphological traits for drought tolerance in rabi sorghum [Sorghum bicolor (L.) Moench]. Int. J. Curr. Res. Biosci. Plant Biol. 6(9), 24-32. doi: https://doi.org/10.20546/ijcrbp.2019.609.004 